\title{
Civilisational Renewal through Spiritual Revival
}

\author{
Reza Shah-Kazemi*
}

Islamic civilisation is the diversified crystallisation of the essential values of the faith of Islam. These values can be summed up in two principles, one which is 'vertical' and Divine, the other 'horizontal' and human. The Qur'an is the vertical and Divine axis; the soul of the Prophet is the horizontal and human axis: it is at the point where the two intersect that there resides the immensely creative force capable of founding an authentic civilisation. All science, all art, all culture, all philosophy, all spirituality which can in any way be defined as 'Islamic' derives in the final analysis from this point of intersection between the human and the Divine, between earth and Heaven, between prophetic perfection and divine revelation. As regards the nature of the Islamic Revelation, there is not simply intersection between the two axes, but also profound complementarity between the divine Message and the human Messenger: on the one hand, the prophetic character (khuluq) was akin to the Qur'an, as his wife, ' $\bar{A}$ 'isha tells us in a famous narrative; and on the other, his character is described in the Qur'an itself as being 'azim, "tremendous" (68:4) — an adjective used to describe both the Qur'an and God Himself. The tremendousness of the prophetic character is something to which all Muslims can and must aspire, given that he is also described as an uswa hasana (33:21), a 'beautiful role-model'; this moral imperative is reinforced when we consider that he himself identified one of the central aims of his prophetic mission as being the 'perfection' or 'completion' of beautiful character: "I was raised up as a prophet," he said, "in order to perfect the most noble virtues". ${ }^{1}$

This indispensable aspect of the prophetic mission has been ignored or belittled, it seems, by many, if not most, of those concerned with addressing the contemporary crisis of Islamic civilisation. For: 1) there can be no renewal of Islamic civilisation without a creative application of Qur'anic principles to the wide-ranging crises afflicting Muslim societies across the globe; 2) there can be no true creativity in relation to the Qur' an if the interpretive activity of our intellects is not enlivened and empowered by the prophetic paradigm; 3) this paradigm, in its turn, will remain an abstraction unless there be a resolute engagement with the "greatest of all struggles", al-jihād al-akbar: the struggle to rid the soul of its vices, diseases and shortcomings, in its aspiration to realise, to some degree, at least, those "most noble virtues", for the sake of which the Prophet was sent to us; 4) finally, victory in this struggle can only be attained through the remembrance of God, which, like the struggle itself, is called by the Qur'an, akbar, greatest: "And the remembrance of God is greatest" (29:45). The human effort to conform 
to prophetic perfection, on the horizontal plane, is consummated by the 'vertical' grace magnetised by prayer, invocation, contemplation.

It is becoming increasingly clear to sensitive Muslim scholars, philosophers and thinkers generally that the crises afflicting Muslim societies worldwide are so many manifestations of an essentially spiritual crisis. If the fundamental cause of the crisis of Islamic civilisation is spiritual, then this means that its locus is not so much on the social but the individual plane: it is not an abstract social problem, but an irreducibly human one. In other words, the outward crises at the level of society and culture are symptoms of a malaise which is of a radically inward order. While this is readily being admitted by many thinkers and writers, many of the remedies being suggested are, alas, themselves symptomatic of the same spiritual disease: for we are being urged to seek spiritual renewal on the level of the collectivity - which is a reifying abstraction when we are dealing with the concrete life of the spirit. One can reform laws and institutions with the best will in the world, with the finest blue-print, with the most carefully formulated safeguards; but without a reform of the corrupt individuals subject to the redefined laws and composing the revamped institutions, corruption cannot but persist.

It is at the level of the individual, only, that authentically spiritual change can be effected; and there are still strong, if relatively informal, spiritual institutions, groups and networks throughout the Muslim world to which individuals can turn in their effort to effect change at this deeper level. When a sufficient number of individuals bring about change at this level, the effects will be felt, ultimately, on the outward planes of society. Sincere efforts by individuals to reform their hearts and souls will, by the grace of God, transform the very spirit of society; but the converse does not hold: well-intentioned efforts to reform the spirit of 'society' will not necessarily reform the hearts and souls of individuals. The life of the spirit is uncompromisingly and inalienably individual: even if the spiritual life - a life lived in loving emulation of the perfect virtues of the holy Prophet - presupposes ethical propriety and beauty in inter-personal relations, the fundamental source of that ethical life is generated by individual spiritual effort. This effort - like breathing, eating and sleeping - is not something that can be done by others for oneself, nor can one do it for others: it must be done by each individual for himself or herself.

For some, the radical inwardness of the spiritual life of the individual may smack of individualism or even solipsism. In reality, it is the sole solution to what one might call 'spiritual collectivisation', which is a hidden poison infecting so many sincere efforts to renew Islamic life and thought. It is much easier to advise others to reform themselves than to make an effort to reform oneself. Moreover, as the mystics of all religious traditions know by experience, the only 
way to truly escape from the ego and its illusions is by finding a dimension of consciousness which is both within the self and beyond it: a consciousness which is immanent within the individual, but at so deep a level that it is no longer bound by anything pertaining to the individual. It is, in other words, transcendent 'in depth'. Discovering this dimension of consciousness is tantamount to liberation not just from egotism but from the ego as such. The intimacy of the relationship thus established with God, far from being 'individualistic' is of incalculable benefit to humanity; it is to this mysterious interpenetration of personal sanctity and universal compassion, inward realisation and cosmic blessings, that the holy Prophet alludes in various sayings.

But even to appreciate the existence of this liberating consciousness within the soul requires some degree of engagement with a spiritual discipline. This discipline is both active, in a sense that is obvious: prayer, meditation, invocation, contemplation; and passive, in a sense which is not so obvious, and which is the antidote to one of the most potent forces generating our contemporary crises: the force of worldliness. The antidote to this worldliness is the passive aspect of spiritual discipline, namely, zuhd (spiritual detachment). One thinks here not only of the holy Prophet himself but also of such companions as the second caliph, 'Umar: in his life one sees an inspiring contrast between inwardly implacable detachment from the world and outwardly stunning success in the world. Conversely, when the world is deemed to be of absolute importance, when one's all-devouring concern is to put right the 'civilisational crisis', however this be conceived, then one is in danger of contributing to the spiritual malaise through an unwitting worldliness: a worldliness manifested by the desire to reform the world rather than oneself. In other words, from spiritual laziness comes the strong temptation to justify one's laziness by frenetic activity for the sake of 'the world'.

"Your ailment comes from yourself, but you do not perceive it," Imam 'Alī tells us in one of his poems; "and your remedy is within you, but you cannot see it." In other words, the affliction that comes from oneself is to be remedied by that which is in oneself, and that which is within oneself is the fitra, the perfect, primordial nature which is our birth-right, and the seed of the liberating consciousness. It is by means of this fitra that we are able to recognise and emulate the prophetic perfection, for the Prophet is "closer to the believers than their own selves" (33:6), on the one hand; and on the other, he is described as being "within you (fikum)" (49:7), and also as being "from yourselves (min anfusikum)" (9:128). Reflecting on these verses, the great Persian poet Rumi says that the prophets and the saints remind us of our true, original state of primordial perfection: the soul cries, upon seeing the Prophet, "I come from this and I belong to this."

To quote Rumi again: "Those who acknowledge the truth see themselves in the Prophet and hear their own voice proceeding from him. No man denies his 
own self." ${ }^{\prime 4}$ In this light, invoking blessings upon the Prophet — an indispensable element in the spiritual life in Islam - can be viewed as a fundamental means of self-realisation. These considerations bring us back to the sayings of Imam 'Alī, for immediately after the verses cited come the following ones:

Although you see yourself as an insignificant speck,

within you the greatest world is contained;

You are thus yourself the meaningful Book [Q 43:2 et passim];

whose letters make manifest that which is concealed.

The inward dimension is thus not only a 'microcosm', a 'small world'; it is in fact a kind of 'metacosm', in that it contains 'the greatest world', al-'alam al-akbar. This is why the struggle to put right this world within the soul is called al-jihäd al-akbar, it is an infinitely 'greater' struggle than that which is required to put right the world outside oneself. "You are thus yourself the meaningful Book" (al-kitāb al-mubīn), and this equation is intimately bound up with the complementarity between the Prophetic soul and the Qur'an: it is only insofar as we tend towards our deepest self, our fitra, which is empirically manifested to us in the form of the Prophet, that we can begin to glimpse the implications of the fact that we ourselves constitute the meaningful Book. Divine Revelation will thus be found within oneself: "We shall show them Our signs upon the horizons and in their own souls, so that it be clear to them that this is the Truth" (41:53). From this inner revelation of divine Truth arises the creative power that - by the grace of God, and with the collaboration of a 'critical mass' of kindred spirits - is capable of effecting a renewal on the 'civilisational' plane; for we are told that, "God will not change the condition of a people until they change the condition of their own souls" (13:11). We thus return to the source of both civilisational renewal and spiritual revival, the point of intersection between the two dimensions of Islamic faith, vertical and horizontal, celestial and terrestrial, divine and human: lā ilāha illa'Llāh, and Muhammadun rasūlu'Llāh.

\section{Notes}

* Reza Shah-Kazemi is Managing Editor of Encyclopaedia Islamica, the English translation and edition of the on-going multi-volume Persian Great Islamic Encyclopaedia (Da'irat al-Ma'arif-i Buzurg-i Islami).

1. This hadìth is found in the collections of Ibn Hanbal, al-Bayhaqī and al-Hākim al-Nīsābūrī.

2. 'Alī b. Abī Ṭālib, Dīwān, ed. 'Abd al-Raḥmān al-Mușțāwī (Beirut and London, 2005), 72.

3. The Discourses of Rūmī (Fīhi mā fìhi), trans. A. J. Arberry (London: John Murray, 1961), 44-45.

4. Ibid., 227. 